\title{
The Impact of Trade Balance of Agri-Food Products on the State's Ability to Withstand the Crisis
}

\author{
Dragan Dokić ${ }^{\mathrm{a}} \mathbb{0}$, Mirna Gavran ${ }^{\mathrm{b}}$, Maja Gregić ${ }^{\mathrm{b}}$, Vesna Gantner ${ }^{\mathrm{b}}$ \\ ${ }^{a}$ Erdut Municipality, Bana Josipa Jelačića 4, Dalj, Croatia. \\ ${ }^{b}$ Faculty of Agrobiotechnology Osijek, University of Josip Juraj Strossmayer in Osijek, Osijek, Croatia.
}

Received 02 July 2020; Revised 19 August 2020; Accepted 21 August 2020; Published 01 September 2020

\begin{abstract}
The crisis represents a disorder that in contemporary society is increasingly occurring. Crises are often the result of some earlier solution. The situation in agricultural production in Croatia has been negative for years. Inadequate taxation and high administrative burdens act to discourage the production process and impede the competitiveness of farmers. Furthermore, the measures taken to create added value are not enough; they can even be said to be wrong. The current crisis, COVID-19, has caused a disturbance in the market in terms of trends in supply and demand. The crisis period will show whether the country has an adequate strategy to overcome all the economic problems ahead. The aim of this paper was to analyze the readiness of the Republic of Croatia for crisis periods in terms of food security by analyzing the volume of agricultural production, the balance of foreign trade in agri-food products, and the structure of total agri-food product trade. The determined trend of increasing deficits in agri-food products in the foreign trade balance, particularly with EU countries, implies the state's unenviable position regarding food security, indicating the need for the implementation of adequate measures in the direction of the market organization and to facilitate investment in sustainable agriculture production systems.
\end{abstract}

Keywords: Crisis; Agricultural Production; Competitiveness; Import; Export; Business Efficiency.

\section{Introduction}

Recessions and crises as phases of economic cycles in the real sector are mostly explained by the accumulated imbalances in the underlying macroeconomic aggregates over time, but this does not explain why these imbalances occur at all [1]. The forms of crisis escalation are manifold: the decadence of culture, the stagnation of economic prosperity, the breaking of trade ties, the collapse of recently stable production systems, the confusion of social order and the state, and others [2]. Emerging market economies are facing an outflow of foreign capital, which was especially pronounced at the time of the previous economic crisis. Such countries have experienced a weakening of their currencies, even at double-digit rates. Foreign banks in these countries experienced losses from their claims in local currencies and experienced difficulties in collecting foreign currency-denominated loans. Madžar (2010) [1] stated that the production decline in most countries is sharp and highly synchronized. Already in scientific circles, there is speculation about big losses, even though the crisis caused by the COVID-19 virus is only in its initial stage. Precisely because of the threat to the life and health of people, states have adopted measures restricting the movement of people, but in this context, industry is suffering. This prevents the movement of capital, the workforce, the smooth circulation of money and other economic activities that are part of everyday life. The crisis, which threatens to affect

* Corresponding author: dragan.dokic79@gmail.com

\section{doi) http://dx.doi.org/10.28991/HIJ-2020-01-03-02}

$>$ This is an open access article under the CC-BY license (https://creativecommons.org/licenses/by/4.0/).

(C) Authors retain all copyrights. 
not only individual countries but also the world economy due to its complexity, will require a systematic approach to finding a solution [3]. This is an opportunity for transition countries to gain insight into some of the key determinants of their current aspirations in the fields of institution-building and economic policy orientations by looking at the deep determinants that caused the economic crisis.

The crisis reveals some aspects of economic trends and social interactions that are not visible in "normal", stable conditions [4]. The crisis, whether caused by market or state deficiencies, has a negative impact on all economic and financial parameters and has a worrying effect on all market and public sector entities, i.e., all citizens in the state. The crisis is slowing and reducing production, sales, and investment, leading to layoffs and rising unemployment, reducing Gross Domestic Product (GDP) and standards and quality of life [5]. For politicians, the crisis is not only the most difficult economic problem but also a special political problem [2]. Without credit expansion, supply and demand tend to equalize through free price adjustment, so there is no opportunity for either cumulative expansion or cumulative depression. What happens if banks opt for credit expansion to stimulate economic activity (investment)? Credit expansion involves the creation of a credit mass that is above the level provided by voluntary savings. It is only an initial impulse, which means for the market a "new fact" to which market participants adapt. Thus, the effects of credit expansion are transmitted throughout the entire economic system [6]. The primary cause of cyclical fluctuations lies in changes in the amount of money in circulation, which inevitably leads to a disruption of the price system ("counterfeiting" of price signals) and, consequently, misdirection of production. Changing the amount of money in circulation leads to a change in the price level [7]. With the change in the amount of money in circulation, relative prices change, and therefore the structure of production. It is necessary to implement such theoretical thinking into the economic system of the Republic of Croatia, that is, to direct investment funds to the development of those agricultural capacities that produce the highest market yields and from which the wider social community benefits.

The aim of this paper was to analyse the readiness of the Republic of Croatia for crisis periods in terms of food security by analysing the volume of agricultural production, the foreign trade of agri-food products as well as the structure of total agri-food product trade.

\section{Material and Methods}

According to data from the Register of Agricultural holdings (Agency for Payments in Agriculture, Fisheries and Rural Development, APRRR), in year 2018, 167,676 farms were registered, of which 162,248 were family farms (hereinafter referred to as FF) and which make up $96.8 \%$ of the total number of farmers. Besides the family farms, agricultural activity performed 2,187 trades, 2,690 companies, 355 cooperatives and 196 legal entities of other organizational forms. Compared to year 2017, the number of farms increased by 3,217 farms or $2 \%$. Farmers used a total of $1,133,851.8$ ha of agricultural land, which is an increase of $0.9 \%$ over year 2017. The largest number of farmers in year 2017, 119,430 uses areas up to 4.99 ha (accounting for $71.2 \%$ of the total number of farmers). In year 2018 the number of these small farmers increased by $4.9 \%$. furthermore, in year 2018, on average, one farmer uses 6.8 ha of farmland. In terms of organizational form, the largest holdings are farms that use an average of 66.7 ha of agricultural land, as follows:

- Cooperatives, which use on average 40.1 ha of agricultural land per cooperative;

- Trades, which on average use 33.8 ha of agricultural land per trade;

- Other organizational forms of farms use an average of 20 ha of agricultural land and;

- FFs, which use an average of 5.3 ha of agricultural land per family farm.

Table 1. Comparative view of agricultural production, import and export (MP, 2019) [8]

\begin{tabular}{ccccccc}
\hline Product & $\begin{array}{c}\text { Production in 2018, } \\
\text { ton }\end{array}$ & Average production in 2013-2018 & $\begin{array}{c}\text { Export, } \\
\text { ton }\end{array}$ & $\begin{array}{c}\text { Export in } \\
\text { mil Euro }\end{array}$ & $\begin{array}{c}\text { Import, } \\
\text { ton }\end{array}$ & $\begin{array}{c}\text { Import in } \\
\text { mil Euro }\end{array}$ \\
\hline Corn & $2,147,275.00$ & $1,868,920.00$ & $516,694.00$ & 91.13 & $41,309.00$ & 26.14 \\
Wheat & $738,363.00$ & $809,786.00$ & $506,074.00$ & 89.71 & $163,254.00$ & 28.53 \\
Sunflower & $110,790.00$ & $110,117.00$ & $63,218.00$ & 21.20 & $3,402.00$ & 5.27 \\
Vegetables & $152,899.00$ & $151,336.00$ & $20,221.00$ & 26.14 & $103,478.00$ & 117.41 \\
Fruit & $213,910.00$ & $213,360.00$ & $16,983.00$ & 14.58 & $204,112.00$ & 187.90 \\
Cattle & $414,125.00$ & $413,936.00$ & $43,824.00$ & 45.90 & $130,636.00$ & 73.10 \\
Pigs & $1,049,123.00$ & $1,049,996.00$ & $282,065.00$ & 40.90 & $485,759.00$ & 23.00 \\
Poultry & $11,413,000.00$ & $10,658,366.00$ & $10,087,072.00$ & 6.70 & $8,998,781.00$ & 5.40 \\
\hline Total & & & & $\mathbf{3 3 6 . 2 6}$ & & $\mathbf{4 6 6 . 7 5}$ \\
\hline
\end{tabular}


The agricultural production accordingly to the products (corn, wheat, sunflower, vegetables, fruit, cattle, pigs, and poultry) in year 2018, as well as import and export are presented in Table 1. In terms of exports, a positive balance is achieved in the production of corn, wheat, sunflower, pigs and poultry. Furthermore, the negative balance is realized in the production of vegetables, fruits and cattle.

\section{Results and Discussion}

International trade flows are of great importance from the standpoint of the development of the domestic economy and the wider environment. Bajec et al. (2004) state that no economy can base its growth on the self-sufficiency of real and financial resources, and is therefore directed to international trade, whose final balance reflects the degree of growth and macroeconomic variables of a particular economy [9]. Comparison of import and export value in Croatia for year 2018 is presented in the Figure 1. According to the value of export-import ratio, agricultural products were exported in amount of 336.26 million of Euro, while agricultural products were imported in amount of 466.75 million of Euro, which represents a deficit of 130.49 million of Euro.

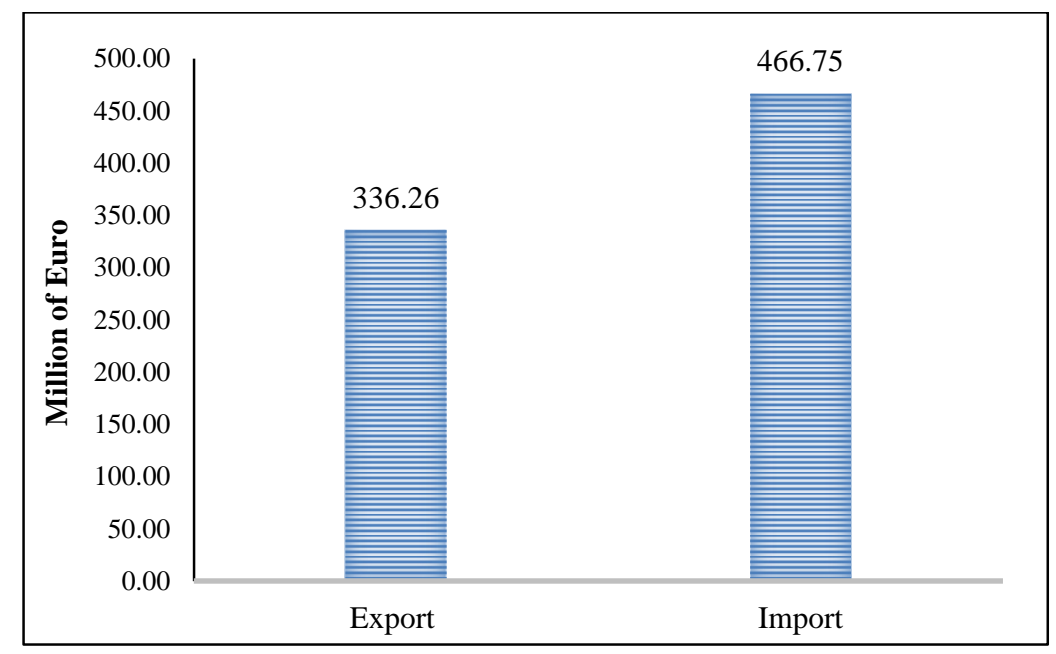

Figure 1. Comparison of import and export value in millions of Euros in Croatia in year 2018

In order to obtain a complete picture of the situation in agriculture, it is necessary to coordinate the food industry and the exchange of these products in addition to primary agricultural production. Foreign trade of agricultural and food products on the basis of data from the DZS (2018) [10] in year 2018 shows that agri-food products were imported in amount of 3,094.0 million of Euro, while amount of exported products worth 2,082.4 million of Euros, resulting in a deficit of 1,011.6 million of Euro (Figure 2). In the period from year 2013 till 2018 the increasing trend of exported and imported agri-food products was determined, with highest values in year 2018. Also, the highest deficit was determined in the same year. Furthermore, in the overall balance of trade of Croatia, the balance of foreign trade in agri-food products in year 2018 was $11 \%$.

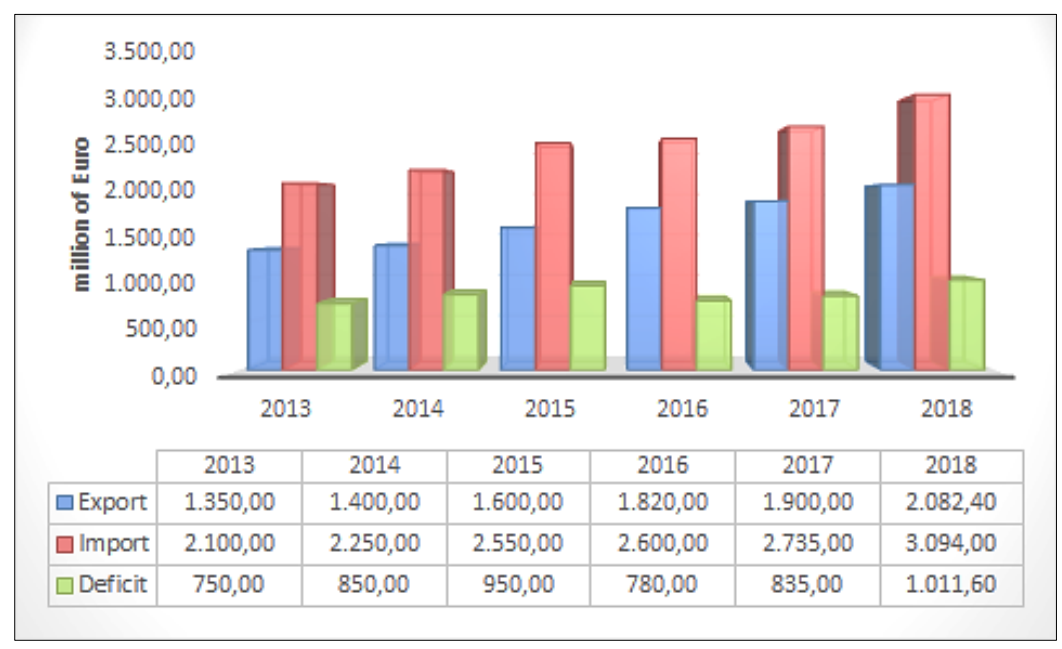

Figure 2. Foreign trade of agri-food products of Croatia in period from year $2013-2018$

In year 2018, in the structure of total agri-food product trade, the most traded countries were Member States of the European Union and CEFTA (Figure 3). With the EU Member States, 78.2\% of the total value of the agri-food trade was realized, while with the CEFTA countries it was $15.1 \%$. In trade with CEFTA countries, a surplus of 366.2 million 
of Euros was made, while in trade with EU Member States a deficit of 1,380.8 million of Euros was generated.
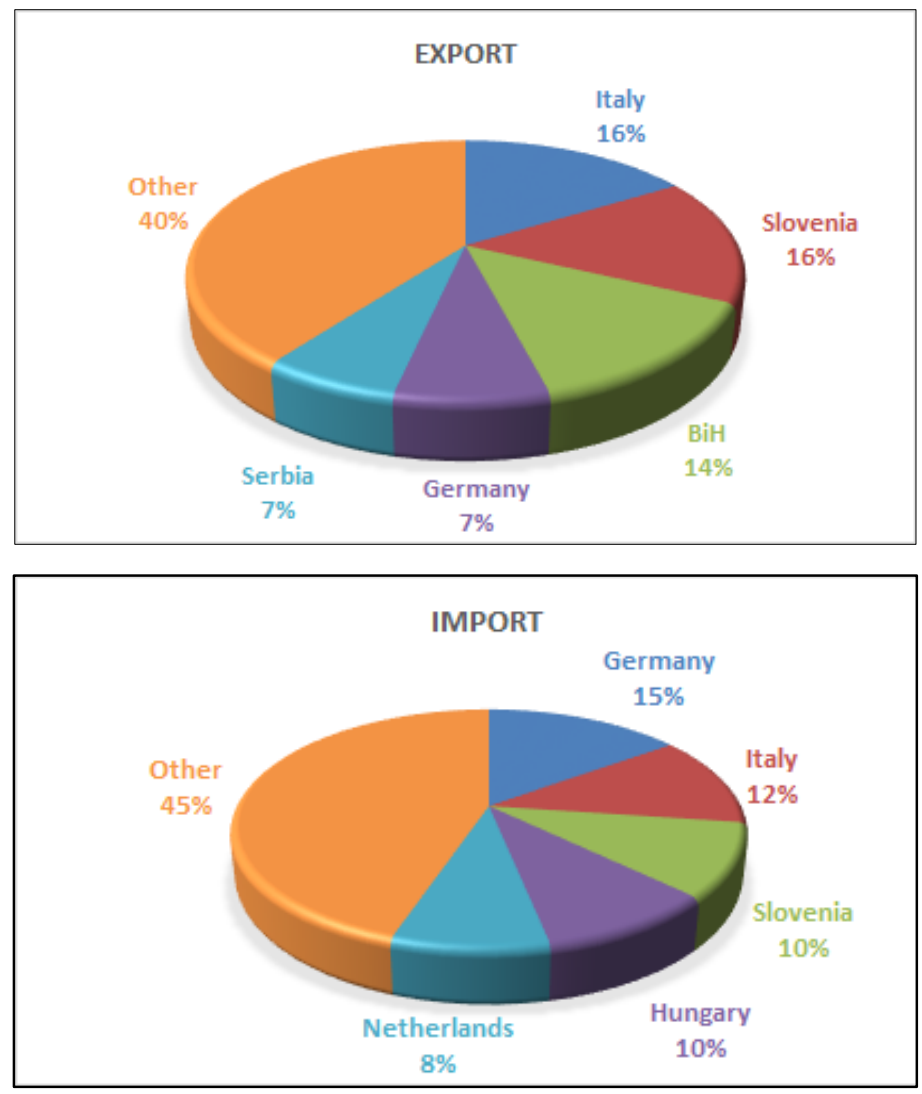

Figure 3. The most important export and import markets of Croatia in agri-food products in year 2018

The results indicate that Croatia is heavily dependent on import policy. In the event of an economic crisis and adverse economic flows when production is expected to decline and prices increase, the volume of imports will decrease, but it is very likely that the cost of imports will remain at the same level or even increase. It is therefore necessary to turn to our own capacities. Croatia cannot, by its actions, prevent the global economic crisis, but it can certainly take appropriate measures on a continuous basis to mitigate its impact [11]. The process of deindustrialisation must be finally stopped, otherwise Croatia will not solve the issue of unemployment and foreign trade deficit even in the medium term, while in the long term it will be condemned to technological backwardness. Insisting on the development of the service sector is a concept that should not be implemented as primary. Primary production is the real sector (economic activity that results in some material value for which production requires adequate knowledge, industry or agriculture). All this points to the necessity of implementation of industrial policy. The goal of industrial policy is to create conditions for sustained and rapid economic growth, above all industry [12], which will contribute to overall economic growth and improve living standards, and in the event of a crisis, strengthen the country. The recapitalization of companies, cooperatives and family farms will strengthen their competitive position. This should be achieved through various measures that increase productivity [9].

The government is responsible for policies that will encourage the development of domestic companies, improve infrastructure, and in particular knowledge infrastructure, as well as effectively maintain essential non-profit sector activities that provide the basic conditions for attracting desirable foreign investment. All developed countries have full confidence in their own economic science and are developing an original model of industrial policy. With the active role of the state, long-term industrial policy and social consensus, positive economic results can be achieved, as evidenced by the example of Germany and Japan in the post-war period. Another of the state measures is the implementation of expansionary fiscal policy through incentives, reduction of tax pressure, all with the aim of helping the domestic market. The fiscal stimulants that affect the increase in supply through increased demand are: the granting of investment incentives and reduction of tax rates and social security contributions to reduce labour costs; granting consumer loans to citizens and corporate loans; increase social benefits for certain categories of citizens, financial assistance for the unemployed and poor households. The state has also taken over a considerable part of the interest rate management from the market through the reference interest rate, which it uses as a factor in influencing the supply and demand of money and capital in the financial market and as an incentive for investment and employment. An open market policy, in which the government issues securities mainly on the basis of a public loan, affects the amount of money in the market and its price $[13,14]$. After all, it is obvious that an investment climate must be created that will 
give an absolute advantage to the real sector of the economy, as it is only one that can provide stability, growth and development.

\section{Conclusion}

In the event of an economic crisis that seems unavoidable, Croatia will face short- and long-term challenges, the resolution of which will depend on the model of the crisis exit strategy chosen. The speed and extent of state intervention are influenced by political factors, and each country has to identify the segments it protects through recovery plans. The activities and measures to be implemented by the state need to be directed to the real sector in order to strengthen its own production potential and thus compensate for losses in the medium term due to dependence on agricultural imports. Getting out of the crisis will be neither easy nor quick. The economic slowdown and rising unemployment are problems that will be present. The obtained results show that it is necessary to implement measures that strengthen their own capacities. These measures should reduce the negative balance of imports relative to exports, that is, increase the level of competitiveness for industry. The recovery and continuous strengthening of the real sector also benefit future crises. Economic vibrations should be reduced to minimize damage. In other words, the state must provide stable sources of financing for the domestic economy, as it will thus preserve its companies and labour force and thereby raise its rating with foreign investors.

\section{Declaration of Competing Interest}

The authors declare that they have no known competing financial interests or personal relationships that could have appeared to influence the work reported in this paper.

\section{References}

[1] Bracke, T., Bussière, M., Fidora, M., \& Straub, R. (2010). A Framework for Assessing Global Imbalances1. The World Economy, 33(9), 1140-1174. doi:10.1111/j.1467-9701.2010.01266.x

[2] Lardy N.R. (2009). China`s Role in the Origin and Response to the Global Recession, Speeches, Testimony, Papers, Peterson Institute for International Economics, 12, 156-158.

[3] Crotty, J. (2009). Structural causes of the global financial crisis: a critical assessment of the 'new financial architecture'. Cambridge Journal of Economics, 33(4), 563-580. doi:10.1093/cje/bep023.

[4] Stiglitz, J. E., \& Gürkaynak, R. S. (Eds.). (2015). Taming Capital Flows. Palgrave Macmillan, London, United Kingdom doi:10.1057/9781137427687.

[5] Jonung, L. (2009). The financial crisis of today: a rerun of the past, European Economy News, No. 12, Magazine of the Directorate-General for Economic and Financial Affairs, European Commission, Brussels, Available online: https://lup.lub.lu.se/search/ws/files/75262877/0273_001.pdf (accessed on 10 March 2020).

[6] Staehr, K. (2015). The Choice of Exchange Rate Regime in Emerging-Market and Transition Economies. Palgrave Dictionary of Emerging Markets and Transition Economics, 60-91. doi:10.1007/978-1-137-37138-6_5.

[7] Lux, M., Gibas, P., Boumová, I., Hájek, M., \& Sunega, P. (2016). Reasoning behind choices: rationality and social norms in the housing market behaviour of first-time buyers in the Czech Republic. Housing Studies, 32(4), 517-539. doi:10.1080/02673037.2016.1219331.

[8] Hrvatska, R. (2019). Ministarstvo Poljoprivrede (MP): Pravilnik o metodologiji za praćenje stanja poljoprivrednog zemljišta. Narodne Novine, 47, Zagreb, Croatia. Available online: http://extwprlegs1.fao.org/docs/pdf/cro165537.pdf (accessed on May 2020).

[9] Bajec, J., Fabris, N., Galic, J., Mitrovic, S., \& Spasic, M. (2004). SWOT Analysis of Serbia and Montenegro's Accession to the EU. Transition Studies Review, 11(3), 42-56. doi:10.1007/s11300-004-0004-1

[10] Croatian Bureau of Statistics, DZS. (2018) Statistical Yearbook of the Republic of Croatia. Zagreb, Croatia. Available online: https://www.dzs.hr/Hrv_Eng/ljetopis/2018/sljh2018.pdf (accessed on May 2020).

[11] Đokić, I., Fröhlich, Z., \& Rašić Bakarić, I. (2015). The impact of the economic crisis on regional disparities in Croatia. Cambridge Journal of Regions, Economy and Society, 9(1), 179-195. doi:10.1093/cjres/rsv030

[12] Kynčlová, P., Upadhyaya, S., \& Nice, T. (2020). Composite index as a measure on achieving Sustainable Development Goal 9 (SDG-9) industry-related targets: The SDG-9 index. Applied Energy, 265, 114755. doi:10.1016/j.apenergy.2020.114755

[13] Andolfatto, D., Berentsen, A., \& Martin, F. M. (2019). Money, Banking, and Financial Markets. The Review of Economic Studies, 87(5), 2049-2086. doi:10.1093/restud/rdz051.

[14] Long, W., Li, S., Wu, H., \& Song, X. (2019). Corporate social responsibility and financial performance: The roles of government intervention and market competition. Corporate Social Responsibility and Environmental Management, 27(2), 525-541. doi:10.1002/csr.1817. 